\title{
The Four 'I's: Quality Indicators for the Humanities
}

\author{
Wilhelm Krull and Antje Tepperwien
}

\begin{abstract}
In a period, in which many things seem uncertain and yet everything is calculated and measured, the humanities can hardly avoid the evaluative quality measurement. However, a look into the world of benchmarks, ratings and rankings reveals that the oftentimes culture-specific performances of humanities research and teaching are almost immaterial therein. From the perspective of a private research funder, among others the following questions are traced: To what extent do international standards of quality exist in the humanities? Which criteria are suitable? Do assessment methods exist that allow for an adequate evaluation of performances in the humanities? To what extent should the humanities get involved with the construction of a publication and citation industry? What chance of survival do the humanities have in a world predominantly characterized by science and engineering?
\end{abstract}

\section{Ranking Fever in Germany}

A new era in German and European academic activities was launched on June 23, 2003, when the first Academic Ranking of World Universities (ARWU) was published by the Center for World-Class Universities (CWCU) at the Graduate School of Education (formerly the Institute of Higher Education) of Shanghai Jiao Tong University, China. It has been updated on an annual basis ever since. ${ }^{1}$ The methods and criteria upon which the ranking is based are disputed, as the chosen indicators yield a strong bias favouring universities in English-speaking countries that focus

\footnotetext{
${ }^{1}$ On the Shanghai Ranking, see 'Academic Ranking of World Universities' at http://www.arwu. org.
}

W. Krull · A. Tepperwien ( $\varangle)$

VolkswagenStiftung, Kastanienallee 35, 30519 Hannover, Germany

e-mail: tepperwien@ volkswagenstiftung.de

W. Krull

e-mail: krull@volkswagenstiftung.de 
on science and engineering. ${ }^{2}$ Nevertheless, since the first 'Shanghai ranking' was published, Germany, like most other European countries, has been caught up in a ranking fever. This is evident not only in the nearly hysterical reaction to each new update of the ranking but also in the growing number of more or less 'homemade' national ranking lists that have appeared in recent years in diverse newspapers and periodicals. $^{3}$

A quick look at these ranking lists shows how great the current demand for quantifiable assessment of the quality of teaching and research at German universities apparently is: The news magazine Focus, for instance, publishes an annual ranking of German universities that seeks to find out where in Germany the best research and higher education can be found based on surveys among professors, citation analyses and data from the German Federal Statistical Office. The news magazine Der Spiegel turned the tables, so to speak, and produced a ranking together with AOL and McKinsey that uses an online survey to assess the excellence of a university not based on the performance of its professors but on the achievement level of its student body (grades on school-leaving examination and university intermediate examinations). The business newspaper Handelsblatt, for the interests of its target group, reports on the top researchers and top faculties in the field of economics. The Hochschulanzeiger [higher education gazette] in the newspaper Frankfurter Allgemeine Zeitung compares the career success of graduates of private business schools in German-speaking countries. The newspaper Karriere chooses the best universities in the fields of economics, law, media sciences, mechanical engineering, electrical engineering, industrial engineering and computer science based on a survey of graduates, personnel managers and data from the German Federal Statistical Office. The Wirtschaftswoche business magazine publishes the results of a survey of 200 researchers on 'where Germany's best researchers in the 12 most important future technologies work' and also surveys personnel managers on the quality of graduates in economics, law, engineering sciences and computer science.

The Centre for Higher Education Development (CHE) in Germany would like its ranking to stand out among the others: First published in 1998, the CHE University Ranking covers study programs and is multidimensional. ${ }^{4}$ However, this ranking,

\footnotetext{
${ }^{2}$ The following six indicators are decisive for a positioning in the Shanghai ranking: the number of alumni winning Nobel Prizes in physics, chemistry, medicine, or economics and Fields Medals in mathematics (10\%); the number of staff winning a Nobel Prize or Fields Medal $(20 \%)$; the number of articles written and co-authored by staff and published in the journals Nature and Science (20\%); the number of published articles written by staff and indexed in Science Citation Index - Expanded and Social Sciences Citation Index $(20 \%)$; the number of highly cited researchers at the university in 21 different fields (20\%); and per capita academic performance with respect to the size of the university (10\%). On the Shanghai ranking criteria and criticism of the criteria, see, for example, http://www.che-ranking.de/cms/?getObject=108\\&getLang=d. Accessed 2 May 2014.

${ }^{3} \mathrm{An}$ overview of the rankings is provided at the website of the Centre for Higher Education Development (CHE) at http://www.che-ranking.de/cms/?getObject=47/\&getLang=de. Accessed 2 May 2014.

${ }^{4}$ On the CHE University Ranking, see http://www.che-ranking.de.
} 
too, does not find favour with all universities and with all disciplines. For instance, the Verband der Historikerinnen und Historiker Deutschlands [Association of Historians in Germany] published a statement in 2009 refusing participation in ratings or rankings such as those conducted by the CHE (Historikerverband 2009).

\section{The Reaction of the Humanities to the Ranking Fever}

The historians' association's disapproval of rankings and ratings is an example of the difficulties that arise from the increasing demand for quantifiable evaluation of research in the humanities and social sciences. The historians' association not only rejects the larger and smaller forerunners, offshoots and competitors of the Shanghai ranking but also does not support the efforts of the Wissenschaftsrat (German Council of Science and Humanities) to put forward a differentiated research rating as an alternative to the overly simple and often methodologically unsound rankings by private providers: After lengthy discussions, the historians' association refused in 2009 to participate in a research rating conducted by the Wissenschaftsrat, which had previously conducted ratings in sociology and chemistry (Historikerverband 2009).

The historians' association acknowledged the intention of the Wissenschaftsrat to rate different fields in a differentiated manner and according to a catalogue of criteria negotiated upon by representatives of the fields themselves, in contrast to the procedures by other rankings. But fundamental doubts as to whether it makes sense to create such a rating and to submit to the demand for quantifiable data led to disapproval by the association. In a statement on April 4, 2009, the then president of the association, Werner Plumpe, said that the opponents of a research rating in the historical disciplines doubt the sense and meaning of such a rating. Plumpe (2009, p. 123) summed up the position of the rating opponents as follows:

Hier könne es allein aufgrund der Unmöglichkeit, ein dynamisches Fach wie die Geschichtswissenschaft parametrisch gleichsam in einer Momentaufnahme abzubilden und wertend zu erfassen, zu keinen sinnhaften Resultaten kommen. Was dabei herauskomme, seien teilweise quantifizierte, immer aber parametrisierte Informationen für politische Diskussions- und Entscheidungsprozesse, die gemessen an der Realität des Faches unterkomplex seien, der Politik aber das Gefühl des Informiertseins durch die Wissenschaft selbst vermittelten. Auf diese Weise bediene der Wissenschaftsrat letztlich die politische Illusion, Wissenschaft lasse sich parametrisch durch das Setzen bestimmter Anreize steuern, und fördere damit die Herausbildung und Verfestigung strategischer Verhaltensweisen, die zumindest in den Geisteswissenschaften die akademische Kultur zerstörten. Das Fach habe es aber weder nötig noch sei es im eigenen Interesse verpflichtet, die gefährlichen Illusionen der derzeit politisch hegemonialen Strömungen zu bedienen.

[Here there can be no sensible results, due already to the impossibility of portraying a dynamic discipline like history parametrically in a snapshot, so to speak, and capturing it in a rating. The result would be partly quantified but always parameterized information for policy discussions and decision processes; the information would be under-complex compared to the reality, but it would give the politicians the feeling of being informed by science itself. In that way, the Wissenschaftsrat would ultimately serve the political illusion 
that science and scholarship can be steered parametrically by setting certain incentives, and this would thus promote the development and hardening of strategic behaviours that at least in the humanities would destroy the academic culture. But the discipline does not find it necessary, nor does it feel obligated in its own interest to serve the dangerous illusions of the current politically hegemonic trends.] (Plumpe 2009, p. 123)

In addition to these fundamental concerns, Plumpe (2009) reported that in the opinion of the rating opponents, it was also questionable how a rating could produce meaningful results unless it were continuously repeated-and would thus cost so much time and work that expenditure would be disproportionate to yield and would devour so much capacity (in the reporting and evaluation process) that it would run counter to the intention to improve the quality of research and teaching.

When the historians' association finally decided in the summer of 2009 not to participate in the rating - to boycott it essentially - their press release stated that it supported the concern of the Wissenschaftsrat to actively participate with the professional associations in reaching agreements on standards in the disciplines and in jointly developing discipline-specific criteria for research quality, but that it had fundamental reservations against the usefulness and feasibility of the rating being planned. In its statement, the association emphasized clearly that German historians were conscious of their responsibility to be accountable to the public and also signaled its willingness to participate in an appropriate form in the search for suitable concepts and in an open-ended discussion on the possibility of developing and measuring quality standards in the humanities (Historikerverband 2009).

This much is certain: In a time when so many things seem uncertain and yet everything is calculated and measured, the humanities can hardly avoid evaluative measurement of quality. A look at the world of benchmarks, ratings and rankings shows, though, that the often culture-specific achievements of humanities teaching and research do not really play a role in them at all. And the instruments used to create rankings do not do justice to the disciplines in the humanities.

\section{Quantity Instead of Quality: Current Methods of 'Quality Assessment'}

Just how unsuitable current methods, such as making the number and impact of publications measurable and verifiable as quality standards, are for quality assessment in the humanities can be shown by a look at the database of Thomson Reuters (originally called the Institute for Scientific Information and still later Thomson Scientific). ${ }^{5}$ Its data analyses can only work in disciplines where the database contains not only the citing works but also the majority of the cited works. Whereas this is so for up to $100 \%$ of the cases in the big disciplines in the natural sciences, this congruence is only $40-60 \%$ in mathematics and economics. In the social sciences and humanities,

\footnotetext{
${ }^{5}$ See http://science.thomsonreuters.com.
} 
the percentage is even much lower. For instance, in literary studies, only $11 \%$ of the works cited are also contained in the database.

This example of the difficulties in assessing quality in the humanities and social sciences using instruments that are geared to the natural sciences was pointed out by Christoph Schneider, who for many years headed the department of scientific and scholarly affairs at the German Research Foundation (Deutsche Forschungsgemeinschaft, DFG). In an article in the Frankfurter Allgemeine Zeitung in October 2009 titled 'Zauberlehrlinge im Rate- und Ränkespiel' [Sorcerer's apprentices in the rating and ranking game], Schneider wrote on the new measurement madness that just as Midas in the Greek myth turned everything that he touched into gold and thus starved to death, evaluators that are obsessed with ranking lists turn everything into numbers, which soon distorts their reality (Schneider 2009).

It is now sufficiently well-known that quality assessment methods that have in part proved their worth in the natural sciences cannot be applied 1:1 to the humanities and social sciences. The differences between the two in their publication and communication cultures are too great. Often there is very little understanding of or knowledge about the 'other side'.

In a 2006 article in Die ZEIT, social psychologist Harald Welzer wrote about his experiences collaborating with a neurophysiologist in an interdisciplinary research project supported by the Volkswagen Foundation. Welzer felt that the often mentioned speechlessness between the disciplines is not it at all; instead it is cultural differences between the disciplines that make it difficult to engage in exchange. Welzer (2006, p. 1, par. 4) asked in Die ZEIT:

\begin{abstract}
Wer hätte sich je Gedanken darüber gemacht, dass die disziplinären Vorstellungen von einer "wissenschaftlichen Veröffentlichung" so voneinander abweichen, dass es fast unmöglich ist, gemeinsam einen Text zu verfassen? Für mich als Sozialwissenschaftler war es höchst befremdlich, noch die stumpfesten Hauptsätze, zu denen ich fähig war, von den Gutachtern eines Fachbeitrags als "episch breit" kritisiert zu finden, während im umgekehrten Fall Gutachter sozial- und geisteswissenschaftlicher Journale Phänomene wie die "zunehmende Reaktionsgeschwindigkeitsverminderung" für ziemlich absonderlich hielten.

[Who ever thought that the disciplinary notions of a 'scientific or scholarly publication' would differ so greatly that it is nearly impossible to jointly write a text? For me as a social scientist it was highly disconcerting to have reviewers of a scientific article criticize even the dullest substantive clauses that I was capable of for being 'epically broad', whereas in the opposite case, reviewers for social sciences and humanities journals deemed phenomena such as 'increasing reaction rate reduction' quite peculiar.] (Welzer 2006, p. 1, par. 4)
\end{abstract}

Whereas in the natural sciences ground-breaking research findings are published in a handful of international journals known to all members of the scientific community in a given discipline, the main form of publication in the humanities continues to be the monograph, which is almost always written in the author's native language. Whereas in the natural sciences people argue about which author of a journal article should be listed in what position, the concept of 'first author' is hardly known in the humanities. In the humanities, excellence is still based mainly on the research achievements of individual scholars and not on the joint efforts of a research team. Current methods of quantitative assessment only very insufficiently take into account these different forms of knowledge creation and publication. 
The amount of third-party funding is another example. Naturally, the natural sciences and engineering play in a very different league here, for their work requires in part expensive equipment and materials as well as support by technical personnel. In addition, they pay their research assistants, at least those with doctorates, full salaries. A researcher in the humanities, in contrast, requires mainly time, a good library and possibly money for trips to archives or for field research. For the humanities scholar, the time to conduct research gained by the funding of his position or of a temporary stand-in for his position is as valuable as the costly laboratory equipment is for the natural scientist. But for the third party, this type of research is of course considerably less costly, and in the third-party funding statistics it makes up approximately one-tenth of the amount of third-party funding that is customary in engineering and medicine. ${ }^{6}$ If management boards of universities look only at the amount of external funding granted to researchers, they are in essence comparing apples and oranges. And they are also in danger of taking mere activity measures for evidence of achievement.

At present, therefore, the comparatively recent drive to assess quality in numbers puts the humanities rather at a disadvantage. At least they feel pressured and once again pushed into a corner. But it is clear even to critics of the current rankings and ratings that in the long term they cannot evade this trend towards assessment and evaluation. So the question is how to evaluate quality in the humanities appropriately.

\section{Quality Assessment within a Discipline: The Evaluation Culture in the Humanities}

Within the academic community assessment takes place constantly: when positions are filled, appointments are made, scientific or scholarly works are accepted by publishers, and third-party funding is granted. This quality assessment is based for the most part on criteria recognized within the community that are not measurable in numbers and that adhere to performance criteria.

A look at peer reviewers' reports provides deep insight into customary quality evaluation methods within a discipline. The Volkswagen Foundation, which funds research in all disciplines, is dependent on peer review of the research grant applications submitted by applicants. Some general things hold for all peer reviewers' reports, such as, for instance, that reports that recommend not funding a project tend to be longer than reports that recommend approving a project for a grant. But also in the peer review and assessment culture there are some fundamental differences between the humanities and the natural sciences. The Volkswagen Foundation sends a leaflet to all peer reviewers asking them to assess the following general criteria in their written reports (VolkswagenStiftung 2013, p. 2):

\footnotetext{
${ }^{6}$ See here, for example: Berghoff et al. (2009). Das CHE-Forschungsranking deutscher Universitäten 2009. Gütersloh, Germany: Centrum für Hochschulentwicklung.
} 
1. Contribution to the further development of research:

What place does the proposal take within the framework of the scientific or scholarly development in the respective area? What is new and original in the approach? What will be the benefit in terms of new knowledge to be acquired?

2. Clear-cut description and consistency:

Does the project proposal reflect the present state of the art? Are the objectives clearly defined and attainable? Are the proposed methods and the working scheme adequate in order to achieve the project goals?

3. Personal qualification:

What about the competence of the project staff, their publication record (also in consideration of their biography, e.g. family phase) and the preparatory work for the project?

4. Adequate extent of time, staff and consumables:

Are the estimated time, staff and consumables really required to achieve the proposed objectives? On which budget items could savings be made or funds be reallocated?

5. Recommendations on the realization:

Does the peer reviewer have helpful suggestions for conducting the project that, should the grant be approved, should be communicated anonymously to the grant applicant?

The Volkswagen Foundation lists these same aspects for the review of grant applications in all disciplines. The standards applied are of course the standards that are valid in the respective scientific or scholarly community from which the grant application comes. The peer reviews of grant applications are usually considerably longer in the humanities than in the natural sciences and engineering, and as to contentdepending on the particular culture in the respective discipline-are more critical in their examination. In the humanities, even grant applications that in the end are unreservedly recommended for funding by the peer reviewer are often analysed in detail and criticized. Sometimes, there is an amazing discrepancy between the accompanying assessment sheet, on which the peer reviewer rates the applicant on criteria such as qualifications in the specific field, interdisciplinary potential and research chances for the future, and rates the project on quality, originality and complexity on the one hand, and the peer reviewer's lengthy written report on the other. Even if the peer reviewer gives an overall rating of 'excellent' on the assessment sheet, that does not mean that the grant application will not be taken apart point by point by the peer reviewer in the written report. In-depth examination of a grant application by an esteemed peer is seen as a 'token of love', so to speak, or for the peer reviewers, who see themselves as equals, as a kind of 'matter of honor'. This type of evaluation may work within the discipline, but where humanities scholars are competing with natural scientists for funding, this culture has a negative impact on the humanities' chances of winning. In the Volkswagen Foundation, for instance, this can be seen with the Lichtenberg Professorships, which are open to applicants in all disciplines. 
And also in the context of the Excellence Initiative, as well as in several multistage review and selection processes, this difference in the evaluation cultures has all too often had a negative effect on the humanities' chances of success. ${ }^{7}$

But within the humanities, quality assessment functions more or less smoothly. It is usually not difficult for a peer or an editor at an academic publishing company to determine the quality of the work of an individual researcher. But how do humanities scholars communicate their evaluation culture, which is so frequently accompanied by fundamental criticism of the proposed research questions and methods, to colleagues in the natural sciences and engineering? And how do they handle it when they are expected to measure the quality of a department or an entire faculty and have to explain their evaluation results using numbers and facts in a way that the public can understand and verify?

Up to now, the humanities still owe an answer to the question of how quality can be 'measured' in the respective disciplines appropriately. There is no doubt that the instruments for quality assessment used in the natural sciences and engineering cannot be applied to the humanities. Those instruments are also not appropriate for several other disciplines, because often-as it appears, at least-today's rankings and ratings use quantitative and quantifiable criteria and disregard non-quantifiable criteria, as non-quantifiable criteria can be determined only at considerably greater expense. But if there is a demand for reference to qualitative criteria, the following question has to be answered: What is quality in the humanities?

\section{What Is Quality in the Humanities? Looking Back}

A central topic in humanities research is the analysis of past times, or more precisely, recording, revealing and conveying cultural material as an important part of our cultural heritage. Perhaps to answer the questions as to what quality is in the humanities and how it can be measured we need to look not only at the present and at other countries but also at the past, at the heyday of humanities research in Germany. Why are the late 1800s and early 1900s characterized as a kind of heyday? This is because of the then international impact of German humanities research, the great attractiveness of the German universities for students and scholars from abroad, and the transfer to other countries of forms of teaching and research methods developed in Germany.

What about that impact today? Whereas the natural sciences and engineering have settled on a more or less good laboratory English as the lingua franca, the vast majority of the humanities disciplines remain bound to national languages. The decline of

\footnotetext{
${ }^{7}$ On funding decisions in the Excellence Initiative, see http://www.dfg.de/foerderung/programme/exzellenzinitiative/allgemeine_informationen/index. html. Accessed 2 May 2014.
} 
German as a language of science and scholarship as well as the decreasing importance of German-language acquisition are inextricably linked. But disciplines that work in and through language cannot simply throw off the respective language. Humanities scholars have to write in the language in which they think, and at the same time they must learn several languages so as to be able to participate in the scholarly debates in other countries. ${ }^{8}$ In a certain way, the following comment by Jutta Limbach, former president of the Goethe Institute, also holds true for the humanities: 'Englisch ist ein Muss, Deutsch ist ein Plus' [English is a must, German a plus] (Limbach 2005 , p. 3). If research quality of the humanities can be measured among other things via international attractiveness, then this does not mean that this attractiveness can be increased by the number of courses of study taught in English offered in the humanities. Instead, it is the bilingual or trilingual courses of study that are conducted in cooperation with universities abroad that can increase the international visibility and attractiveness of the German humanities. Exchange programs and the presence of up-and-coming young scholars and established professors at international conferences promote the networking of the international academic community in all humanities disciplines and make possible the exchange of research findings and methods and, with this, at the same time also make the high quality of humanities research in German-language countries visible in international circles.

Measurement of quality in the humanities along the same lines as in the natural sciences and engineering does not work. The fact that quality in the humanities is more difficult to quantify does of course not mean that quality does not exist. Even though the international attractiveness of the humanities disciplines in Germanspeaking countries has declined, its transmission has not faded. ${ }^{9}$ Humanities scholars trained here, if they also possess the needed language competency, have good chances on the international research labor market. However, the high qualifications of the up-and-coming researchers say only so much about the quality of a discipline in research and teaching. Only a small percentage of university students enrolled in humanities programs seek an academic career or even have any chance at all to have a successful research career, despite the fact that studies at German universities, especially in the humanities, are still frequently mainly geared to qualifying students for research careers. In Germany, a large part of the humanities disciplines belong to the massively attended study programs with high numbers of students, unfavourable teacher-student ratios and in part dramatic drop-out rates. ${ }^{10}$

\footnotetext{
${ }^{8} \mathrm{~A}$ conference on the topic Deutsch in der Wissenschaft [German in science] was held at the Akademie für Politische Bildung in Tutzing from January 10-12, 2011. The papers were published in a conference volume (Oberreuter et al. 2012).

${ }^{9}$ See Behrens et al. (2010). Die internationale Positionierung der Geisteswissenschaften in Deutschland. Eine empirische Untersuchung. Hannover, Germany: HIS-Projektbericht.

${ }^{10}$ For a current analysis of the situation of the humanities in Germany, see the recommendations of the Wissenschaftsrat on development and promotion of the humanities in Germany (Wissenschaftsrat 2006).
} 


\section{The Critical Self-image of the Humanities}

Summing up the discussion in and about the humanities in Germany, the following picture emerges: Long disregarded by government, poorly equipped, underfunded and standing practically no chance in the competition for the big third-party public funds, the humanities seem to eke out a pitiful existence. ${ }^{11}$ The critical self-image of the humanities, which was being clearly expressed already in the 1980s, can be illustrated by the following three quotations:

Joachim Dyck, a Germanist at the University of Oldenburg, lamented in an article in the periodical Die ZEIT as early as 1985:

Wo noch vor 15 Jahren die Rede- und Ideenschlacht tobte, gibt es heute als Geräusch nur noch die leise Klage der Hochschullehrer über die dürftigen Schreib- und Leseversuche einer sprachlos gewordenen Generation und den beflissenen Wortschwall von Studenten, deren abgeleiertes Referat vom meditativen Klappern der Stricknadeln begleitet wird, in der Hoffnung, dem geistigen Leben durch handwerkliche Nebentätigkeit noch einen Hauch von Sinn abzuringen.

[Where 15 years ago there was a wild war of words and ideas, today there is only the sound of the university teachers' soft complaint about the meager attempts by a generation gone speechless to read and write and the assiduous torrent of words of students whose reeling off of their presentations is accompanied by the meditative rattle of knitting needles, in the hope of wresting some small sense out of the intellectual life by engaging in handicraft.] (Dyck 1985, p. 2)

In 1989, philosopher Jürgen Mittelstraß wrote on the splendor and misery of the humanities as follows:

Über den Geisteswissenschaften liegt nämlich ein wissenschaftsideologischer Fluch, den 1959 Charles Percy Snow, Physiker, Romancier und hoher britischer Staatsbeamter mit seiner Rede von den zwei Kulturen, der naturwissenschaftlichen und der geisteswissenschaftlichen ('literarischen') Kultur in die Welt gesetzt hat. Er tat dies eher nebenbei, in einer Art Sonntagsrede und doch mit ungeheurer Wirkung, vor allem bei den Geisteswissenschaftlern. Diese Wirkung besagt denn auch vielleicht nicht so sehr etwas über den Wahrheitsgehalt der Snowschen Vorstellungen, als vielmehr etwas über die Nervosität und den Selbstzweifel, die die Geisteswissenschaften ergriffen haben.

[There is a curse on the humanities, a science ideology curse that was introduced into the world in 1959 by British physicist, novelist and high government official C. P. Snow in his lecture on 'The Two Cultures', namely, the sciences and the humanities (or literary culture). Snow did this rather incidentally, in a kind of crowd-pleasing speech, but it had enormous impact, especially among humanities scholars. The impact possibly says not so much about the truth of Snow's ideas and very much more about the nervousness and self-doubt that had seized the humanities.] (Mittelstraß 1989, p. 7)

And finally, Hans-Joachim Gehrke, former president of the German Archaeological Institute in Berlin, wrote the following in the DFG journal Forschung in 2008: 'In vielen geisteswissenschaftlichen Fächern steht man bereits mit dem Rücken zur Wand. Weitere Kürzungen werden in manchen Bereichen unmittelbar zum Exitus führen' [Many humanities disciplines are already standing with their backs to the wall. In some fields any further cuts will lead directly to exitus] (Gehrke 2008, p. 3).

\footnotetext{
${ }^{11}$ On the self-image of the humanities, see also Koschorke (2007).
} 
Instead of joining in the chorus of complaints, in the following we will attempt, going beyond the Gekränktheitsrhetorik [offended rhetoric] (a term by Peter Strohschneider), ${ }^{12}$ to point out not only risks but also and especially development opportunities of the humanities, looking at four areas that all begin with the letter 'I', namely, infrastructure, innovation, interdisciplinarity and internationality. At the same time, we will indicate in what areas quality can be found and possibly also measured in the humanities.

\section{Quality Indicators: The Four 'I's}

The first 'I' stands for infrastructure-the foundation of humanities research. Infrastructure is what the humanities disciplines absolutely should have and should strengthen: Libraries, archives and museums are of fundamental importance for cultural memory and for the study of the cultural foundations of societies. However, these institutions are currently undergoing rapid change and are finding themselves caught between the increasing fast pace in the times of the Internet and the central concern of libraries, archives and museums, namely, the long-term availability of their holdings. By promoting simultaneity, interactivity and open access, the new media also open up quite new possibilities for research. But we need to be concerned about the neglect of the permanence of the documentations-short-term life as a consequence of fast availability! Here the task is to assure and protect quality.

The second I stands for innovation. This word has so many facets, all of them associated with renewal, novelty and change, that it is difficult to define the term precisely. For many humanities scholars, who see themselves as custodians of their own and others' traditions (Gehrke 2008, p. 3), the concept of innovation and also nearly any future orientation is the opposite of their central concern. They view as their very own and only task the examination of the past-interpretative learning, understanding and imparting traditions. With this attitude, they are in danger of confirming the popular prejudice, often expressed on the part of natural scientists, that says that the humanities deal too much with the ashes of the past as opposed to what is really important, namely, promoting the fire of the future and driving forward scientific and technical research with quickly measurable results. However, this is a false contrast, because a 'fire of knowledge' fed by the here and now alone is all too frequently likely to turn out to be a rapidly extinguishing flash in the pan. However, we can counteract a just as memory-less and unrestrained belief in progress successfully only if we are willing to always create new perspectives and to learn beyond times and borders, in the conviction that the past must always be present in the present day, if we aim to design the future in a responsible way (Krull 2003, p. 32).

In addition to their classical function of cultural memory-namely, mining, saving and conveying the cultural heritage-perhaps the most important function of the

\footnotetext{
${ }^{12}$ Strohschneider, cited in Hinrichs (2007).
} 
humanities is preventive thinking. The latter is designed to advance our potential to reflect on relevant issues and, with this, to contribute towards working out future options more clearly. Particularly in times of great uncertainty, preventive thinking is more than ever an indispensable task of the humanities. Here lies the innovation potential of humanities research; the full utilization of that potential is without question a quality criterion for humanities research. This, of course, is a criterion that materializes only in idea-rich communication and interaction both within research and also at the interface of research and the public.

The third I stands for interdisciplinarity. In academia itself, the disciplinary orientation dominates: Individual disciplines' reference systems with regard to quality assurance (standards), certification through the awarding of academic degrees, reputation, stability of the field and not least career prospects stand in the foreground. They make up, so to speak, the university's organizational form of knowledge.

But government, economy and society expect researchers to provide solutions for the 'big' questions and not just small and fragmented answers from the perspective of one discipline. In the attempt to establish a balance between the necessary raising of the specialist field profile of the individual discipline and the also necessary bundling of research and teaching capacity, what is practiced for the most part is a kind of contact-free, added-on interdisciplinarity. Due to cost-benefit considerations, usually no effort at all is made to produce common methodological procedures or joint publications. This is even often considered to be extremely career-damaging.

In the age of measurements of science that are oriented towards the leading journals in the different fields, this discipline-specific publication strategy may have an understandable rationality, especially for up-and-coming scholars, particularly as the time cycles of research funding (with still predominantly two- to three-year funding periods) practically promote a narrow focus. However, this should be counteracted against and long-term perspectives should be opened up, so as at the same time to encourage researchers to be willing to take risks and to step outside disciplinary boundaries. If the humanities make their contribution towards answering the big questions and make that contribution visible to the outside world, then they will also be demonstrating their high standards of research quality and importance to society.

The fourth I focuses on internationality, which was already mentioned above. Research is inconceivable without international cooperation. At the same time, European integration and the process of globalization are presenting a particular challenge to education, science, research and technology. If the university is to remain attractive and alive as a place for teaching, research and innovation, then it will be essential to develop a culture of intercultural openness and internationality. The humanities in particular can contribute towards the creation of new perspectives and learning options that transcend borders and times.

Particularly with regard to the risks and opportunities of globalization processes there are still a lot of open questions. For this reason, what is needed is stronger research collaboration across disciplinary, institutional and national borders; only on the basis of new knowledge can the future global challenges be tackled effectively. For future research projects, this means that they must make the process of globalization a constitutive aspect of the respective project architecture. This requires, for one, the 
integration of researchers from different disciplines and cultures and, for another, steady networking with a circle of researchers worldwide, who can all make their contribution in the horizon of the research question. The other way around, effective utilization of globalization opportunities also makes necessary increasing acquisition of culture-specific knowledge. The humanities should increase their commitment also in this area and should make international exchange, international networking and international cooperation an important criterion for quality assessments.

\section{Closing Remarks}

Today's almost simultaneous production, processing and communication of new knowledge also makes necessary a new self-understanding of science, scholarship and research: a shift from a homogeneously structured process firmly anchored in institutions and characterized by disciplinary discourses to a more open process that is often kicked off by questions from outside the discipline and characterized by a firm connection to society as well as problem-oriented methods.

There is a reason why the humanities in Continental Europe hid from these changes for too long: The model being followed - the research university and its disciplinary top-level research-made Germany a world leader in science and scholarship in the nineteenth century. But already beginning in the 1890s, scientific developments mainly in the natural sciences and engineering began to break up Humboldt's unity of research and teaching, which had been raised practically to an ideology. In an essay on the creation of the German research university, Brocke (2001, p. 386) wrote that the increasing inability of the institution of the university to do equal justice to the tasks confronting it—classical education, professional training and scientific researchcaused a constantly growing discrepancy between the neohumanist conception of the university and the universities' actual structure.

Thus, the problems of the Continental European university system virulent today were already marked out at the start of the twentieth century: the insufficient consideration of new disciplines in the traditional university structure, the increasing specialization in all fields, the impossibility of interdisciplinary research within the given structures (which were mostly vehemently defended by the professors) and not least the resulting explosion of costs in the natural sciences and engineering, which through the necessity for savings had a negative impact on the humanities.

The undoubtedly justified sense of pride in an exemplary and productive university system in the past became a counterproductive mentality of protection of vested interests and blindness to scientific, scholarly and societal reality. For this reason it seems all the more urgent now-despite the many difficulties in everyday university operations - to look forward to new possibilities and options. Particularly considering the globalization processes mentioned above, the humanities can definitely profit from the institutional context of increasingly internationalizing universities. To benefit, however, the humanities must be willing to participate more than before in present-day debates and training needs. 
There is no reason for the humanities to remain 'with their backs to the wall' or to give up all hope in the face of the supremacy of the natural sciences and engineering. It would also be wrong to overeagerly adopt the research and evaluation modalities of the natural sciences and to artificially create indices for the humanities. The European Reference Index for the Humanities (ERIH) promoted by the European Science Foundation and the controversies over its methodology and meaningfulness will suffice here as an example to point out that the appropriateness of such measurement methods should be called into question. ${ }^{13}$

One thing is clear: Humanities research requires a different kind of 'measurement' and promotion instruments than the instruments used in the natural sciences. If the quality assessment instruments customary in the natural sciences and engineering were applied 1:1 to the humanities, it would only be to the humanities' disadvantage and would lead to a false snapshot showing only a distorted picture far from reality. Nevertheless, the humanities must make stronger efforts to develop criteria and measurement instruments that go beyond the usual activity measures for assessing good housekeeping. They should make quality in the humanities visible, understandable and recognizable not only within the community in specific disciplines but also to the outside world and to the public. Naturally, it can make sense for the humanities to utilize the usual publication and third-party funding indicators as comparison measures. However, they should be embedded in a clearly structured benchmarking concept that can be used to evaluate comparable institutions - such as, for example, German universities with rich traditions and equipped with a high capacity in humanities teaching and research, such as the universities of Bonn, Göttingen, Heidelberg, Tübingen and Freiburg. A concept of this kind might possibly be realizable also across national borders in the European university and research area and could lead to actual 'learning by comparing', if it combined quantitative and qualitative elements of evaluation.

The humanities are very important for the investigation of past problems, the analysis of present-day changes and for coping with future challenges. The humanities can also serve as a reliable compass in times of rapid change if they themselves are clear about their specific quality and significance and demonstrate this to the outside world. The humanities should not respond to the omnipresent call for quality measurement by inappropriately adopting the practices of other disciplines or by fighting a futile defensive battle. Instead, the response should be a committed, interdisciplinary debate, conducted in international dialogue, on suitable methods of transparent quality assessment in the humanities, which know how to utilize quantitative indicators and at the same time combine them with qualitative evaluation methods.

Open Access This chapter is distributed under the terms of the Creative Commons AttributionNoncommercial 2.5 License (http://creativecommons.org/licenses/by-nc/2.5/) which permits any noncommercial use, distribution, and reproduction in any medium, provided the original author(s) and source are credited.

The images or other third party material in this chapter are included in the work's Creative

${ }^{13}$ See, for example, the opinion of philosopher Stekeler-Weithofer (2009). 
Commons license, unless indicated otherwise in the credit line; if such material is not included in the work's Creative Commons license and the respective action is not permitted by statutory regulation, users will need to obtain permission from the license holder to duplicate, adapt or reproduce the material.

\section{References}

Behrens, J., Fischer, L., Minks, K.-H., \& Rösler, L. (2010). Die internationale Positionierung der Geisteswissenschaften in Deutschland. Eine empirische Untersuchung. Hannover: HISProjektbericht.

Berghoff, S., Federkeil, G., Giebisch, P., Hachmeister, C.-D., Hennings, M., Roessler, I., et al. (2009). Das CHE-Forschungsranking deutscher Universitäten 2009. Gütersloh: Centrum für Hochschulentwicklung.

Dyck, J. (1985). Stumm und ohne Hoffnung. Die totale Paralyse der Germanistik in den 80er Jahren. Die Zeit, 25. Retrieved from http://www.zeit.de/1985/25/stumm-und-ohne-hoffnung.

Gehrke, H.-J. (2008). Erfolg auf wackeligen Beinen. Was die Geisteswissenschaften fördert - und was sie bedroht. Forschung, 1, 3 .

Hinrichs, P. (2007). Platons Erben. UniSPIEGEL, 3, 8-12. Retrieved from http://www.spiegel.de/ spiegel/unispiegel/d-51609364.html.

Historikerverband. (2009). Pressemitteilung: Ausschuss des Historikerverbandes beriet über Forschungsratings in den Geisteswissenschaften und über den Historikertag 2010. Retrieved from http://www.historikerverband.de/fileadmin/_vhd/bilder/Pressemitteilung_WR_Rating.pdf.

Koschorke, A. (2007). Über die angebliche Krise der Geisteswissenschaften. APuZ, 46, 21-25.

Krull, W. (2003). Zwischen Tradition und Innovation. Die Geisteswissenschaften im erwei-terten Europa. In Germanistentreffen Deutschland - Italien. 8.-12.10. (2003). Dokumentation der Tagungsbeiträge (pp. 29-44). Köln: Deutscher Akademischer Austauschdienst.

Limbach, J. (2005). Ich liebe unsere Sprache. Rede im Rahmen der Berliner Lektionen anlässlich der Berliner Festspiele 2005. Retrieved from http://www.goethe.de/mmo/priv/367926-STANDARD. pdf

Mittelstraß, J. (1989). Glanz und Elend der Geisteswissenschaften. Oldenburg: Bibliotheks- und Informationssystem der Universität.

Oberreuter, H., Krull, W., Meyer, H. J., \& Ehlich, K. (2012). Deutsch in der Wissenschaft. Ein politischer und wissenschaftlicher Diskurs. München: Olzog.

Plumpe, W. (2009). Stellungnahme zum Rating des Wissenschaftsrates aus Sicht des Historikerverbandes. In C. Prinz, \& R. Hohls (Eds.), Qualitätsmessung, Evaluation, Forschungsrating. Risiken und Chancen für die Geschichtswissenschaften? (pp. 121-126). Historisches Forum. Berlin: Clio-online. Retrieved from http://edoc.hu-berlin.de/e_histfor/12/.

Schneider, C. (2009). Zauberlehrlinge im Rate- und Ränkespiel. FAZ, 228.

Stekeler-Weithofer, P. (2009). Das Problem der Evaluation von Beiträgen zur Philosophie. Ein streitbarer Zwischenruf. Deutsche Zeitschrift für Philosophie, 57(1), 149-158.

VolkswagenStiftung. (2013). Guide to peer review. Retrieved from http://www.volkswagenstiftung. de/uploads/media/peer_review.pdf.

vom Brocke, B. (2001). Die Entstehung der deutschen Forschungsuniversität, ihre Blüte und Krise um 1900. In R. C. Schwinges (Ed.), Humboldt International: Der Export des deutschen Universitätsmodells im 19. und 20. Jahrhundert (pp. 367-401). Basel: Schwabe.

Welzer, H. (2006). Nur nicht über Sinn reden! Die Zeit. Retrieved from http://www.zeit.de/2006/ 18/B-Interdisziplinaritt_xml.

Wissenschaftsrat. (2006). Empfehlungen zur Entwicklung und Förderung der Geisteswissenschaften in Deutschland. Köln: Wissenschaftsrat. Retrieved from http://www. wissenschaftsrat.de/download/archiv/geisteswissenschaften.pdf. 